\title{
Lysosomal $\mathrm{N}$-acetyl- $\beta$ - $\mathrm{D}$-glucosaminidase: interneuronal differences in ac- tivity and molecular forms
}

\section{O. Z. SELLINGER AND JOSEPHINE C. SANTIAGO}

Laboratory of Neurochemistry, Mental Health Research Institute, University of Michigan Medical Center, Ann Arbor, Mich. 48109 (U.S.A.)

(Accepted February 17th, 1976)

The lysosomal $\mathrm{N}$-acetyl- $\beta$-D-glucosaminidase (EC 3.2.1.30) of brain tissue ${ }^{16}$ has been extensively studied in our laboratory ${ }^{7,15-18}$, with particular emphasis on the distinction between its neuronal and glial7,10,19 components. Evidence for two neuronal components in the immature rat cerebral cortex, each with distinct characteristics, was presented in 1973 (ref. 18). More recently, we demonstrated the presence of similar components ${ }^{17}$ in Purkinje cell bodies, bulk-isolated from the immature rat cerebellar cortex ${ }^{14}$. It is of interest that several recent reports describing, inter alia, the existence of $\mathrm{N}$-acetyl- $\beta$-D-glucosaminidase $\mathrm{C}$ in human brain ${ }^{2}$, and the purification of $\mathrm{N}$-acetyl$\beta$-D-glucosaminidase A from monkey and human brain ${ }^{1}$, failed to consider the possibility of differences in cellular origins and hence in the properties of the activities studied.

In this communication we describe differences in the distribution of molecular forms of $\mathrm{N}$-acetyl- $\beta$-D-glucosaminidase in the neurons of 3 different rat brain regions: the midbrain, the brain stem and the hypothalamus. We also report on the solubilization characteristics of $\mathrm{N}$-acetyl- $\beta$-D-glucosaminidase in these and two other brain regions, the striatum and the hippocampus. The results reveal that the different neuronal cell types possess different complements of $\mathrm{N}$-acetyl- $\beta$-D-glucosaminidase activity which, in all likelihood, reflect each cell type's specific performance potential at the lysosomal level.

Neuronal perikarya were isolated by the procedure previously used for the isolation of perikarya from the cerebral cortex with no modifications ${ }^{13}$. Twenty 18-day-old male Sprague-Dawley rats were used in each experiment and perikarya were isolated from 3 brain regions per experiment. The procedure of Glowinski and Iversen ${ }^{3}$ was used for the manual dissection of the brain regions. The mean values in grams of the wet weights of 20 brain regions (number of experiments in parenthesis) were: hypothalamus, 0.39 (4); hippocampus, 1.10 (3); striatum, 1.62 (3); brain stem, 2.48 (5) and midbrain, 2.71 (6). Previously described procedures 7,18 were used for the isolation of a mixed, particulate fraction (Mit, Ly, Mic) enriched in N-acetyl- $\beta$-Dglucosaminidase and for its solubilization by repeated $(3 \times)$ freezing and thawing 18 . 
The neuronal cell bodies, isolated as a pellet, were suspended in $025 \mathrm{M}$ sucrose and were homogenized with 6 up-and-down strokes of a Potter-Elvehjem glassTeflon homogenizer rotating at about $1300 \mathrm{rev} . / \mathrm{min}$. The approximately $20 \%(\mathrm{w} / \mathrm{v})$ homogenate was subjected to differential centrifugation. The nuclear fraction was first removed by centrifuging the homogenate at $1085 \times \mathrm{g}$ for $15 \mathrm{~min}$ in the SS-34 rotor of the Sorvall $\mathrm{RC}_{2} \mathrm{~B}$ centrifuge; this was followed by one 12-min wash and fraction Mit, Ly, Mic was then sedimented at 105,000 $\times \mathrm{g}$ for $2 \mathrm{~h}$ in rotor 65 of the Spinco ultracentrifuge. The volumes of fraction Mit, Ly, Mic subjected to freezingthawing and subsequently centrifuged at $15,000 \times g$ for $1 \mathrm{~h}$ to separate fraction $\mathrm{S}$ and $\mathrm{P}$ (see Tables $\mathrm{I}$ and $\mathrm{II}$ ) ranged between 1 and $4 \mathrm{ml}$ and were proportional to the wet weights of the brain regions.

We have previously shown ${ }^{18}$ that about $85 \%$ of the quantitatively recovered $\mathrm{N}$-acetyl- $\beta$-D-glucosaminidase of fraction Mit, Ly, Mic appears in the supernatant $\mathrm{S}$ as against $65 \%$ following centrifugation at $155,000 \times \mathrm{g}$. Aliquots of fraction $\mathrm{S}$ ( $1 \mathrm{ml}$ for the hypothalamus and $1.7 \mathrm{ml}$ for the brain stem and the midbrain) were centrifuged in 5-25\% (w/v) linear sucrose gradients (Spinco rotor SW-41) for $14.5 \mathrm{~h}$ at $49,000 \times g$ and the gradient collected in 15 tubes ( $13 \mathrm{drops} /$ tube). The colorimetric assay of $\mathrm{N}$-acetyl- $\beta$-D-glucosaminidase activity was described previously ${ }^{7,16}$. One unit of activity is defined as the amount of enzyme necessary to give an $A_{412 \mathrm{~nm}} / \mathrm{h}$ of 1.0. The specsfic activity is in units/mg of protein.

\section{TABLE I}

THE SPECIFIC ACTIVITY* OF N-ACETYL- $\beta$-D-GLUCOSAMINIDASE IN NEURONAL PERIKARYA BULK-ISOLATED FROM DIFFERENT REGIONS OF RAT BRAIN

The designated brain regions were dissected from twenty 18-day-old rats ${ }^{3}$ and neuronal perikarya isolated by the procedure of Sellinger and co-workers? ${ }^{\text {? }}$. The mean protein contents of this fraction in $\mathrm{mg}$ were: hypothalamus, 0.25 ; striatum, 0.52 ; hippocampus, 0.90 ; midbrain, 1.29 ; brain stem, 1.59 . Freezing and thawing was carried out as previously described ${ }^{18}$ with precautions to maintain closely similar protein-volume ratios ${ }^{18}$. Numbers of experiments are shown in brackets.

\begin{tabular}{lcccc}
\hline $\begin{array}{l}\text { Source of neuronal } \\
\text { perikarya }\end{array}$ & $\begin{array}{l}\text { Fraction Mit, } \\
\text { Ly, Mic } \\
\text { before F-T } T^{* *}\end{array}$ & Pellet $(\boldsymbol{P})$ & Soluble $($ S) & $\begin{array}{l}\text { Enrichment*** } \\
(x \text {-fold })\end{array}$ \\
\hline Hippocampus & $106(2)$ & $112(3)$ & $261(3)$ & 2.45 \\
Striatum & $(69-142)$ & $(32-160)$ & $(123-342)$ & 2.22 \\
Hypothalamus & $150(5)$ & $83(4)$ & $334(4)$ & \\
& $(116-168)$ & $(65-103)$ & $(182-678)$ & 1.30 \\
Midbrain & $156(4)$ & $35.6(5)$ & $202(3)$ & 180 \\
& $(112-192)$ & $(21-55)$ & $(158-264)$ & $322(6)$ \\
Brain stem & $178(5)$ & $129(6)$ & $(216-500)$ & 1.70 \\
& $(110-256)$ & $(86-153)$ & $331(4)$ & \\
& $195(5)$ & $126(5)$ & $(162-503)$ &
\end{tabular}

* All values are expressed in units/mg of protein. The range of values is indicated in parentheses.

** F-T: frozen-thawed $3 \times$ (see text and ref. 18$)$.

*** S over parent fraction Mit, Ly, Mic. 


\section{TABLE II}

THE SOLUBILIZATION OF NEURONAL N-ACETYL- $\beta$-D-GLUCOSAMINIDASE*

The preparation of fraction Mit, $\mathrm{Ly}, \mathrm{Mic}$ and its freezing and thawing were as described previously ${ }^{18}$. The wide range of enzyme activities reflects a parallel range of individual neuronal yields. The range of enzyme recoveries*** was within $\pm 15 \%$ of the stated values.

\begin{tabular}{llllll}
\hline $\begin{array}{l}\text { Source of } \\
\text { neurons }\end{array}$ & Hippocampus & Brain stem & Midbrain & Striatum & Hypothalamus \\
\hline $\begin{array}{l}\text { Fraction: } \\
\quad \text { Soluble (S) }\end{array}$ & 46 & 54 & 62 & 71 & 77 \\
$\quad$ Pellet (P) & 54 & 46 & 38 & 29 & 23 \\
S + P** & $38-116(3)$ & $70-509(5)$ & $58-274(6)$ & $32-149(5)$ & $10-39(4)$ \\
Recovery*** & & 68 & 71 & 84 & 48 \\
$(\%)$ & 105 & & & & \\
\hline
\end{tabular}

* Values expressed as percentage of the recovered activity $(\mathrm{S}+\mathrm{P}=100 \%)$.

** Enzyme activity range in stated number of experiments (in brackets). Values are in $A_{412} \mathrm{~nm} / \mathrm{h}$. *** $(\mathrm{P}+\mathrm{S}$ /fraction Mit, Ly, Mic) $\times 100$.

The specific activity of $\mathrm{N}$-acetyl- $\beta$-D-glucosaminidase in the mixed particulate fraction Mit, Ly, Mic which, as established in preliminary experiments, contained between 70 and $80 \%$ of the total neuronal activity, is shown in Table I. The Table reveals that the mean values spanned a two-fold range and tended to be higher in the midbrain and brain stem neurons than in the hippocampal and striatal neurons. Freezing and thawing followed by centrifugation resulted in mean specific activity increases in fraction $\mathrm{S}$ which ranged from a low of $30 \%$ (hypothalamus) to a high of $145 \%$ (hippocampus). Since these findings suggested regional differences in $\mathrm{N}$ acetyl- $\beta$-D-glucosaminidase solubilization and hence in its structural latency within the lysosomes of the different neuronal cell types, we investigated this point in more detail. Table II shows that the ease of solubilization differed regionally, exhibiting a high resistance in the hippocampus and a high susceptibility in the hypothalamus and the striatum. The enzyme from the latter region was the most affected, inasmuch as $71 \%$ became soluble while undergoing a 2.2 -fold enrichment.

Subjecting fraction $\mathbf{S}$ from the midbrain, the hypothalamus and the brain stem to gradient centrifugation ${ }^{18}$ resulted in the specific activity profiles depicted in Fig. 1. The hippocampal and striatal $\mathbf{S}$ fractions were also gradient-sedimented but since the former resembled the hypothalamic and the latter the midbrain profile, they are not shown. Fig. 1 reveals three distinct patterns of $\mathrm{N}$-acetyl- $\beta$-D-glucosaminidase activity: a midbrain (and striatal) pattern with two components sedimenting closely together toward the bottom of the tube and one component virtually not sedimenting at all; a hypothalamic (and hippocampal) pattern, with one 'heavy' and two intermediate components and virtually no 'light' species; and a brain stem pattern in which three distinct activity peaks were found in the 'heavy' portion of the gradient and two in the 'light' one. Previously, we analyzed the $\mathrm{N}$-acetyl- $\beta$-D-glucosaminidase sedimentation 


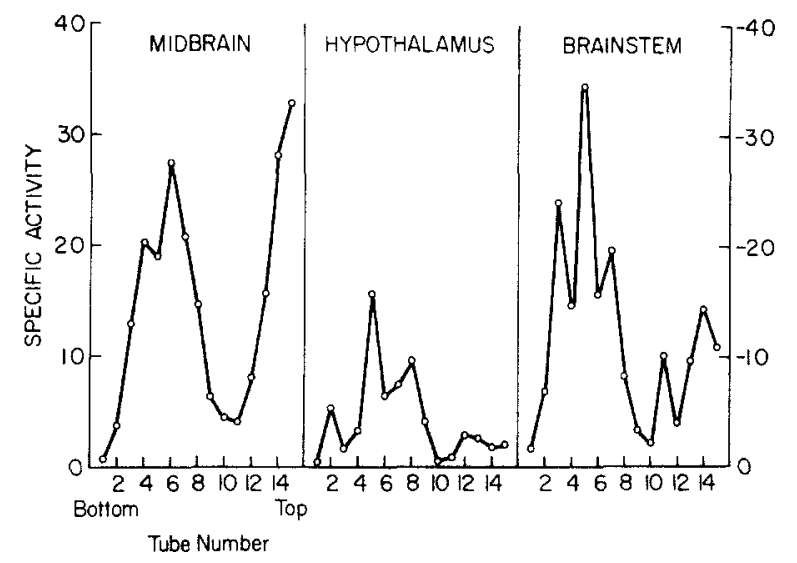

Fig. 1. Sedimentation profiles of solubilızed N-acetyl- $\beta$-D-glucosamınidase in midbrain, hypothalamus and brain stem neurons. Aliquots of fraction S (see text) were layered on a $5-25 \%(w / v)$ linear gradient of sucrose and the tubes centrifuged as described in the text. Activity was assayed in each of the effluent tubes and the units/h values were divided by the protein content in $\mathrm{mg}$ to give the specific activity profiles as indicated. Recoveries of either enzyme or protein were less than quantitative due to pellet formation. The pellets were not analyzed. The profiles as shown were, however, reproducible in terms of peak numbers and sizes.

pattern in bulk-isolated neurons from the cerebral cortex ${ }^{7}$ and in Purkinje cell bodies bulk-isolated from the cerebellar cortex ${ }^{17}$. Both cell types exhibited N-acetyl$\beta$-D-glucosaminidase activity profiles reminiscent of the midbrain pattern (Fig. 1).

Although multiple forms of $\mathrm{N}$-acetyl- $\beta$-D-glucosaminidase have been discovered and characterized in a number of animal and human tissues ${ }^{11}$, mostly by electrophoretic $4,5,9,12,21$ and column chromatographic $8,12,20$ techniques, attempts to assign specific cellular loci to any particular activity component have been scant. Recently, however, Majumder and Turkington ${ }^{8}$ noted that of the 3 components of $\mathrm{N}$-acetyl$\beta$-D-glucosaminidase present in lysosomes of rat epididymal spermatozoa and testes, two were specifically located in the testicular precursor cells, while the third was derived from the acrosomes of the spermatozoa. In brain tissue $1,4,6,7,12$, despite the knowledge that $\mathrm{N}$-acetyl- $\beta$-D-glucosaminidase exists in several forms, there is no precise information as to the partition of these among the different neuronal types. Our previous reports ${ }^{17,18}$, as well as the present one, demonstrate that neurons located in different neuroanatomical loci possess qualitatively different $\mathrm{N}$-acetyl$\beta$-D-glucosaminidase molecular forms. These findings infer that the ability of all neurons to hydrolyze complex glycosphingolipids, including gangliosides, is not the same and that hereditary malfunctions in glycosphingolipid catabolism ${ }^{6,11}$ may therefore involve only a numerically small proportion of neurons lacking one or several minor but essential $\mathrm{N}$-acetyl- $\beta$-D-glucosaminidase components.

This research was supported by the United States Public Health Service, Grant NS-06294. 
1 Aruna, R. N., AND Basu, D., Purification and properties of brain N-acetyl- $\beta$-D-hexosaminidase A, J. Neurochem., 25 (1975) 611-617.

2 Braidman, I., Carroll, M., Dance, N., and Robinson, D , Separation and properties of human brain hexosaminidase C, Biochem. J., 143 (1974) 295-301.

3 Glowinski, J., AND IVERSEN, L. L., Regional studies of catecholamines in rat brain. I. The disposition of ${ }^{3}[\mathrm{H}]$ norepinephrine, ${ }^{3}[\mathrm{H}]$ dopamine and ${ }^{3}[\mathrm{H}] \mathrm{DOPA}$ in various regions of the brain, J. Neurochem., 13 (1966) 655-699.

4 Harzer, K., AND SANDHOFF, K., Age-dependent variations of the human N-acetyl- $\beta$-D-hexosaminidases, $J$. Neurochem., 18 (1971) 2041-2050.

5 Hayase, K., Reisher, S. R., AND Miller, B. F., Purification and separation of A and B forms of N-acetyl- $\beta$-D-glucosaminidase from human aorta, Prep. Biochem., 3 (1973) 221-241.

6 Hooghwinkel, G. J. M., VeltKamp, W. A., OverdiJK, B., AND Lisman, J. J. W., Electrophoretic separation of $\beta$-N-acetylhexosaminidases of human and bovine brain and liver and of TaySachs brain tissue, Hoppe-Seylers Z. physiol. Chem., 353 (1972) 839-841.

7 Idoyaga-Vargas, V., Santiago, J. C., Petiet, P. D., and Sellinger, O. Z., The early post-natal development of the neuronal lysosome, J. Neurochem., 19 (1972) 2533-2549.

8 Majumder, G. C., ANd Turkington, R. W., Acrosomal and lysosomal isoenzymes of $\beta$-galactosidase and N-acetyl- $\beta$-glucosaminidase in rat testis, Blochemistry, 13 (1974) 2857-2864.

9 NeEdleman, S. B., AND KoENIG, H., Isoelectric focusing behavior of acid hydrolases in rat kidney lysosomes. Effects of pH gradient, autolysis and neuraminidase, Biochim. biophys. Acta (Amst.), 379 (1974) 43-56.

10 Raghavan, S. S., Rhoads, D. B., ANd Kanfer, J. N., Acid hydrolases in neuronal and glial enriched fractions of rat brain, Biochim. biophys. Acta (Amst.), 268 (1972) 755-760.

11 Robinson, D., Multiple forms of glycosidases in the normal and pathological states, Enzyme, 18 (1974) 114-135.

12 Robinson, D., Jordan, T. W., AND Horsburgh, T., The N-acetyl- $\beta$-D-hexosaminidases of calf and human brain, J. Neurochem., 19 (1972) 1975-1985.

13 Sellinger, O. Z., Azcurra, J. M., Johnson, D. E., Ohlsson, W. G., and Lodin. Z., Independence of protein synthesis and drug uptake in nerve cell bodies and glial cells isolated by a new technique, Nature (Lond.), 230 (1971) 253-256.

14 Sellinger, O. Z., Legrand, J., Clos, J., And Ohlsson, W. G., Unequal patterns of succinate dehydrogenase and acetylcholinesterase in Purkinje cell bodies and granule cells isolated in bulk from the cerebellar cortex of the immature rat, J. Neurochem., 23 (1974) 1137-1148.

15 Sellinger, O. Z., AND Nordrum, L. M., A regional study of some osmotic, ionic and age factors affecting the stability of cerebral lysosomes, J. Neurochem., 16 (1969) 1219-1229.

16 Sellinger, O. Z., Rucker, D. L., and de Balbian Verster, F., Cerebral lysosomes. I. A comparative study of lysosomal $\mathrm{N}$-acetyl- $\beta$-D-glucosaminidase and mitochondrial aspartate transaminase of rat cerebral cortex, J. Neurochem., 11 (1964) 271-280.

17 Sellinger, O. Z., And Santiago, J. C., Cerebellar N-acetyl- $\beta$-D-glucosaminidase: a study of the enzyme in bulk-isolated Purkinje and granule cells, Neurobiology, 5 (1975) 44-51.

18 Sellinger, O Z., Santiago, J. C., Sands, M. A, and Furin-Sloat, B., N-acetyl- $\beta$-D-glucosaminidase of nerve cells: a developmental study of two molecular components, Biochim. biophys. Acta (Amst.), 315 (1973) 128-146.

19 Sinha, A. K., AND Rose, S. P. R., Compartmentation of lysosomes in neurones and neuropil and a new neuronal marker, Brain Research, 39 (1972) 181-196.

20 SRivastava, S. K., Wiktorowicz, J., Klebe, R., AND Awasthi, Y. C., Studies on $\beta$-D-N-acetylhexosaminidase. Various isozymes in tissues of normal subjects and Sandhoff's disease patients, Biochim. biophys. Acta (Amst.), 397 (1975) 428-436.

21 Yoshikawa, J., Koide, H., And YamanaKa, M., Demonstration of the multiplicity of N-acetylbeta-glucosaminidase by electrophoresis, Biochem. biophys. Res. Commun., 46 (1972) 11-15. 